\title{
Job Satisfaction of Employees and Partners in an Indonesian Government Ministry
}

\author{
Wahyu Nofiantoro $^{1 *}$, Dasril Guntara ${ }^{1}$ \\ Finance and Banking Laboratory, Vocational Education Program, \\ Universitas Indonesia \\ *Email:wahyu@ui.ac.id, dasril.guntara13@gmail.com
}

\begin{abstract}
In responding to strategic environmental change, the directorates of government agencies are heavily influenced by their human resources. One factor that affects the achievement of organizational goals is employee satisfaction because it is a precondition for increased productivity, responsibility, quality, loyalty, and service to customers. The purpose of this research is to examine the level of job satisfaction in one of the directorates of an Indonesian government agency. Data were collected using a survey questionnaire distributed to all civil servants and honorary employees in the Directorate of Government Institutions. The results indicate a good level of satisfaction among respondents.
\end{abstract}

Keywords: job satisfaction, survey

\section{Introduction}

Governance is a very important aspect in people's lives. At a national level, governance is undertaken by bureaucrats who are the government's human resources. Therefore, it is necessary to practice good and professional human resource management in an effort to improve the quality of governance.

Indonesia's recent reform policy expects its directorates to realize the criteria of "Good Governance." Government agencies that have achieved these criteria are notable for a clear strategy, flat (short), lean structure, networking, ability, flexibility, adaptability, and a learning organization approach (Sedarmayanti, 2007).

Based on the Regulation of the Ministry of Trade No. 31/M-Dag/Per/7/2010 concerning Organization and Working Procedures of the Ministry of Trade of the Minister of Trade of the Republic of Indonesia, the Ministry of Trade has made improvements to the organization, including improvement of the organization of the Directorate General of Domestic Trade (Ditjen PDN). This was achieved by sharpening its main duties and functions (tupoksi) and re-grouping of Esselon II units that have tupoksi development, and strengthening of the domestic market.

The organizational restructuring of Ditjen PDN was needed to increase its role in creating added value for stakeholders (community/ people/consumers, business actors, and government). The amendment also aims to be able to answer the challenges that face this organizational unit given the changing strategic environment in the country today. It is understood that domestic trade is a strategic element necessary to create sustainable added value in the value chain. Therefore, the development and security of the domestic market requires a reliable, proactive, and capable organization to address current and future global challenges.

In the operational order, the policy of development and strengthening of domestic trade is done through several strategic programs. One of these programs optimizes the role of service to stakeholders by conducting an in-depth and comprehensive study on the level of job satisfaction of employees and partners of the Directorate General of PDN. "Role of Employee" or "Human Resources" is the authorized capital in determining the purpose of the institution. Without the role of human resources, activities within the institution will not work properly. Humans always play an active and dominant role in every organizational activity because humans become planners, actors, and determinants of the realization of organizational goals (Hasibuan, 2012). Institutional goals can be achieved if employees have high performance. The success of an organization in planning and executing its strategy is supported by the performance of its employees (Hanggarini, 2012). Employee job satisfaction is a prerequisite to improve productivity, responsibility, quality, loyalty, and service to customers of an organization. In addition, employees' satisfaction forms part of the effort to strengthen the organization in order to realize bureaucratic reform toward efficiency and effectiveness of performance (Hasibuan, 2010). 


\section{Formulation of the Problem}

The process of bureaucratic reform demands an increase in the quality of human resources within the directorates of government institutions. Human Resource behavior related to the job satisfaction of each employee is an important element to measure periodically in order to support the success of bureaucratic reform. Therefore, the problem in this study is how the level of job satisfaction of employees and partners against the organization Directorate of Government Institutions.

\section{Methodology}

Data were collected using a questionnaire survey and through in-depth interviews. (Morissan, 2012). Data were statistically analyzed and the results presented below. Qualitative data were collected through in-depth interviews with key informants and focus group discussions (Creswell, 2009).

Table 1. Methodology Framework

\begin{tabular}{|c|c|c|c|}
\hline $\begin{array}{c}\text { Data } \\
\text { Collection } \\
\text { Technique }\end{array}$ & $\begin{array}{l}\text { Sampling } \\
\text { Unit }\end{array}$ & $\begin{array}{c}\text { Number } \\
\text { of } \\
\text { Samples }\end{array}$ & Explanation \\
\hline Survey & $\begin{array}{l}\quad \text { Employees } \\
\text { in the } \\
\text { government } \\
\text { directorate }\end{array}$ & $\begin{array}{l}\quad \text { All } \\
\text { civil } \\
\text { servants } \\
\text { and all } \\
\text { honorary } \\
\text { employees } \\
\quad \text { (+/-30 } \\
0 \text { people) }\end{array}$ & Questionnaire is generic for all employees in the directorate \\
\hline \multirow{3}{*}{$\begin{array}{l}\quad \text { Focus } \\
\text { group } \\
\text { discussion }\end{array}$} & Echelon 3 & $\begin{array}{c}25 \\
\text { people }\end{array}$ & All Echelon 3 officials \\
\hline & $\begin{array}{l}\text { Representat } \\
\text { ion Echelon } 4\end{array}$ & $\begin{array}{c}15 \\
\text { people }\end{array}$ & Three people from each directorate + Sesditjen \\
\hline & $\begin{array}{l}\quad \text { Representat } \\
\text { ion and } \\
\text { honorary staff }\end{array}$ & $\begin{array}{c}25 \\
\text { people }\end{array}$ & Five people from each directorate + Sesditjen \\
\hline \multirow{4}{*}{$\begin{array}{l}\quad \text { In- } \\
\text { depth } \\
\text { interview }\end{array}$} & Echelon 1 & $\begin{array}{c}1 \\
\text { person }\end{array}$ & \\
\hline & Echelon 2 & $\begin{array}{c}5 \\
\text { people }\end{array}$ & Pair with youth informant \\
\hline & Kadin & $\begin{array}{c}1 \\
\text { person }\end{array}$ & \\
\hline & $\begin{array}{c}\text { Local } \\
\text { government }\end{array}$ & $\begin{array}{c}2 \\
\text { people }\end{array}$ & Parallel with FGDs in the province \\
\hline
\end{tabular}

\section{A. Survey}

A survey was conducted using a questionnaire instrument formatted as a structured interview guide. The questions related to Job Satisfaction and Work Productivity. The sampling technique used is the total employee population, this is possible because the survey object coverage is not too large but quite heterogeneous.

\section{B. Interviews}

In-depth interviews were conducted with key informants to explore perceptions about the level of job satisfaction of employees and partners in the directorates of government institutions. 


\section{Focus Group Discussions}

Focus group discussions (FGDs) were convened to explore about the program implementation process, including challenges and problem solving, perceived impacts, program sustainability, and suggestions for improving future programs.

\section{Results and Discussion}

The employee satisfaction survey for employees of the Directorate General of Domestic Trade (DGT) of the Ministry of Trade of the Republic of Indonesia was conducted by collecting primary data by way of a survey, interviews, and discussion groups. There were 40 items of questions related to the condition of the organization and the implementation of the work that occurs and is felt during the work in the Directorate General of PDN. In order to obtain more complete data, respondents were also given the freedom to explain their answers.

Descriptive statistics were applied to the survey data. Data processing is done descriptively by calculating the average value of answer, frequency, and further explanation about the description filled by the respondent. For an average answer $<1.5$ means the average respondent strongly disagree / strongly unfavorable with the questions given, 1.5-2.5 average respondents disagree with the celebration, for $2.5-3,5$ means the average respondent agreed / supported the question. For a value $>3.5$ means the average respondent strongly agreed / firmly answered yes to the question given.

\section{Organizational development}

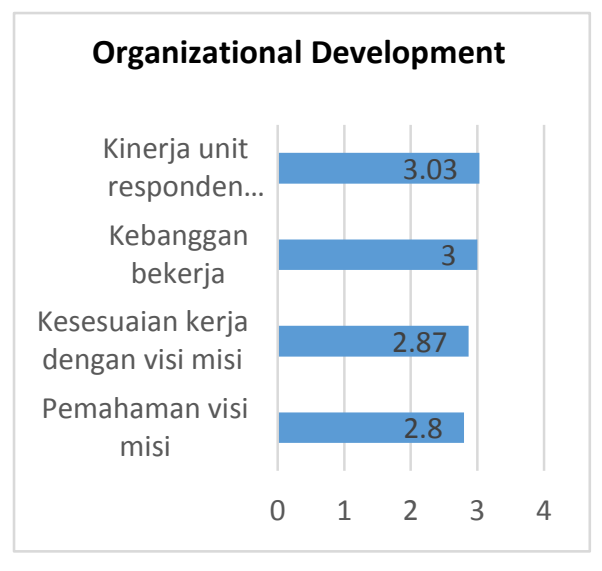

Figure 1. Organizational development

Organizational development within the Directorate General of Domestic Trade is important to be seen as a means to improve the PDN through sharpening tupoksi and organizational restructuring. Increased roles by employees will add value to stakeholders and the quality of service itself, which will be useful for answering strategic environmental change challenges. The development of the organization is important for responding to external challenges while simultaneously strengthening domestic trade. To that end, looking at how the NOP is doing organizational development becomes very important.

The results show that the directorate's vision and mission are not fully understood by employees. This is evident from Figure 1, which shows that understanding of the vision and mission scored 2.8. This means that there are still few employees who understand the vision and mission of the organization. This is directly proportional to the result for suitability of work with the vision and mission with values, which is 2.87 . In fact, domestic trade is part of the strategic value chain of economic development, which spearheads that must be reliable in responding to global challenges and optimizing services to stakeholders.

Based on Figure 1, it can be said that all employees of the Directorate General of PDN understand well the aspects of organizational development at their workplace. Results for the four aspects measured show that performance perceptions (as compared with other units) received the highest score of 3.03 followed by pride in work (3) and work conformance (2.8). 


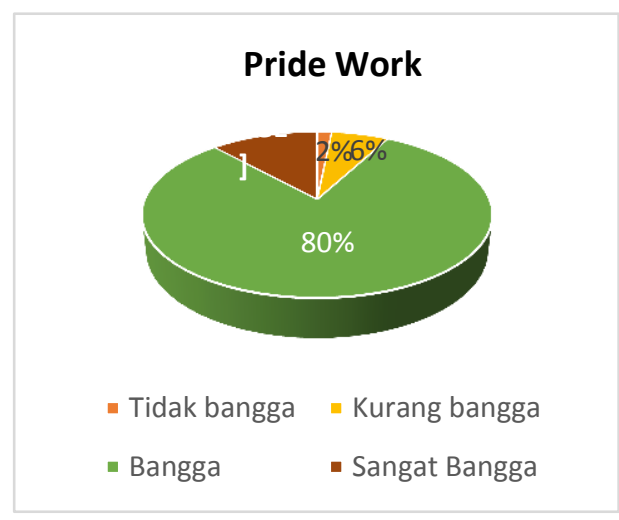

Figure 2. Pride in work

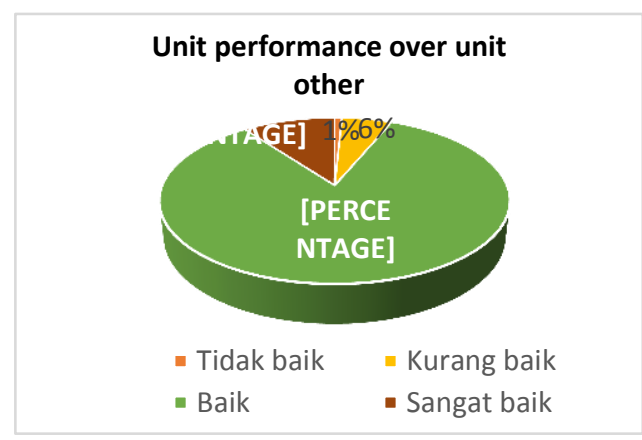

Figure 3. Unit performance over other units

When compared with other indicators, perceptions of the internal performance of the units of the respondents show that they feel proud to be part of their internal units (Figures 2 and 3). This is evidenced by $84 \%$ of respondents saying that their unit performs better than the other units. Pride in working as a team received a positive response from $80 \%$ of respondents. These results indicate a positive modality for organizational development at least at the internal level of the work unit.

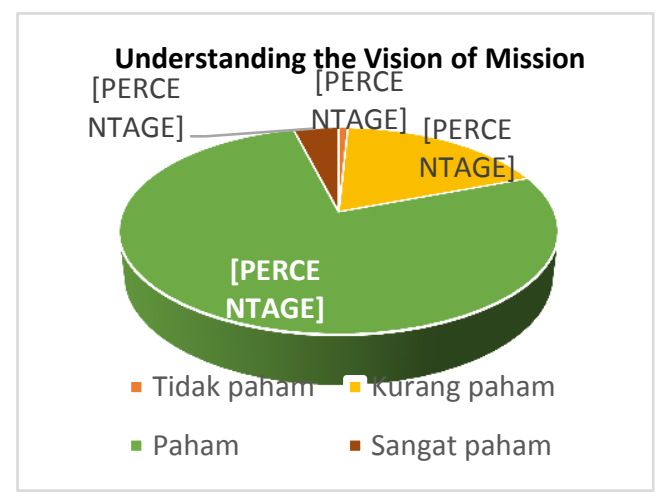

Figure 4. Understanding the vision and mission

In addition, indicators related to employees' understanding of the vision and the mission of the organization and the suitability of employees with the vision also showed a positive response (77\%) followed by $18 \%$ who responded "less understood," $4 \%$ who had a very good understand, and 1\% who they did not understand (Figure 4).

Overall it is good but it only needs a socialization effort to anticipate employees who still feel not understand the vision of the mission of the organization. Then, related to the perception of the employee perception of work kesessuaian with vision vision showed good response with $81 \%$ answer is appropriate, $6 \%$ is very appropriate, $9 \%$ answered less according to $1 \%$ answer is not appropriate. 
Dissatisfaction with organizational development is seen when the employee states that "training" is a mere formality and employees who really need the training materials do not get it. Therefore, the training materials can not be applied significantly in the unit he is working on. It is also related to the workload given, the more employees have a good performance, then he will not be sent to become a training participant. Employees feel lack of development for him.

The civil servant should be regarded as a professional in performing his duties, contributing and maintaining his vision as a public servant and also developing country, but his work can be appreciated for the advancement of Indonesia. - Respondent E, in FGD, November 12, 2014

From the above revelation, it can be seen that the reality in the PDN organization is not in line with the expectations of employees prior to entering the organization. From the critical attitudes displayed in the FGDs, it can be seen that employees are actually qualified human resources, have a strong willingness to support bureaucratic reform, and realize the vision and mission of PDN. However, this is not supported by the organization's ability to manage these changes.

\section{Compensation and other benefits}

Compensation and other benefits are the rewards received by employees (tangible and intangible) or otherwise and can be used to measure employee job satisfaction.

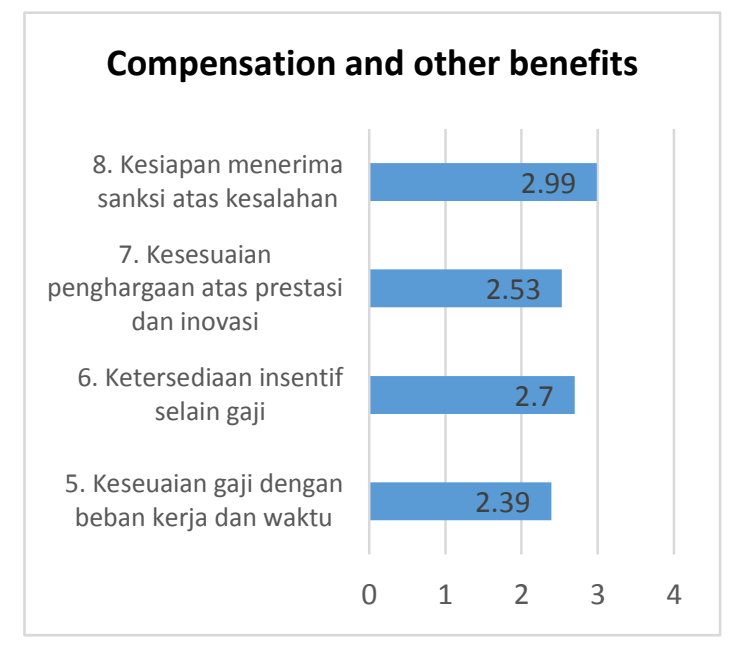

Figure 5. Compensation and other benefits

In the aspect compensation and other benefits, the employment pegwai Ditjen PDN is indicated on several indicators as in the comparison scores above Figure. Overall it can be said that for this aspect has a good value, where all respondents agreed with the existing conditions (Figure 5).

Among the indicators of employee satisfaction, compensation and other benefits are the most responsive from the employee relationship with employee satisfaction. Remuneration in the Ministry of Trade is the most highlighted.

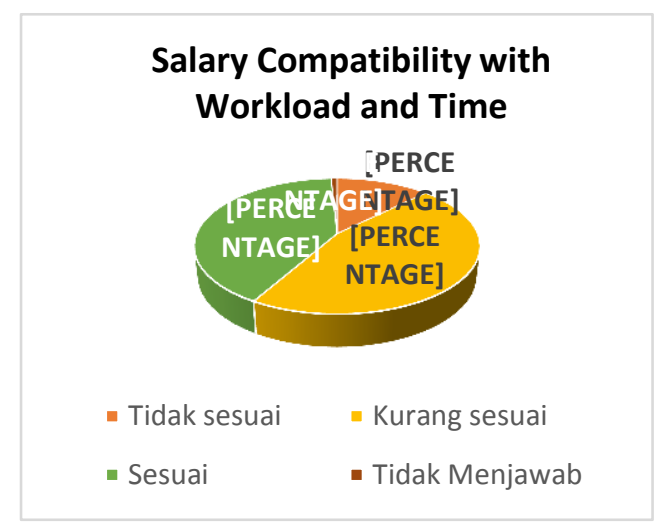

Figure 6. Salary compatibility with workload and time

Almost half of the respondents stated that their salary earned is not appropriate for the workload and time while $40.9 \%$ stated it was appropriate. Based on the FGD results, remuneration in the Ministry of Trade of $47 \%$ 
felt very less by looking at the existing workload. Take-home pay and allowances are less than the cost of living in Jakarta with two children. It also makes the minder when compared with colleagues who work in private. Some employees in certain units feel the hours of work are more than necessary; for example, sometimes staff is needed by $9 \mathrm{am}$ and there is no overtime compensation. For the directorate unit, they still have to remain on stand-by during the weekends (Figure 6).

Meanwhile, there is no evaluation forum for each unit to make proposals or evaluate the leader. Employees do not mind if they have to stay late and come to work on weekends provided that the system is clear (shifting, for example), to maintain stamina and productivity. Employees also claim that if demanding overtime hours becomes a habit, then it is not good.

This is different from the DKM unit, which feels its workload is lighter. There needs to be an adjustment between compensation and workload; for example, in some units, workers are paid overtime for up to three hours while in others workers are paid $\mathrm{Rp} 27,000$ per hour; there are also units that are always home on time (logistics).

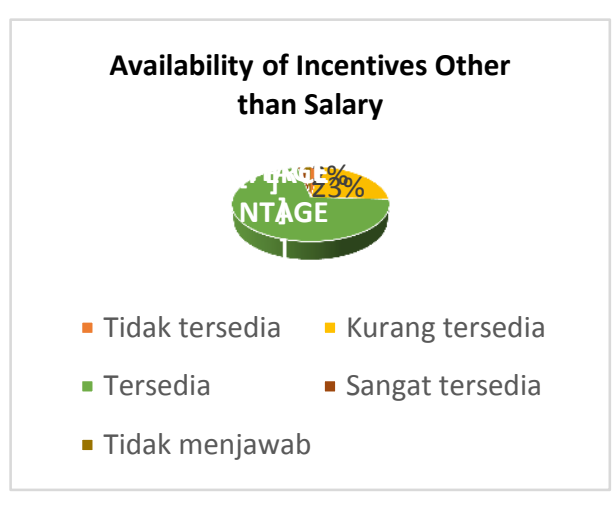

Figure 7. Availability of incentives other than salary

In addition, there is also intensive in addition to salaries that can be aliternatif if employees feel the salary received is still less appropriate. Seventy percent of respondents say that there are incentives in addition to the salary they can receive although these incentives vary widely, depending on the employee's work unit (Figure 7).

In the secretary unit, for example, they have an overtime schedule that is good and clear although it currently only applies to Echelons 3 and 4 . The idea came from the leadership to control the workload and maintain employee stamina in order to remain able to work optimally. However, in other units it is not good. One employee stated:

Indeed, civil servants do dedication, but the compensation is not like in private. If in private the better will get the .

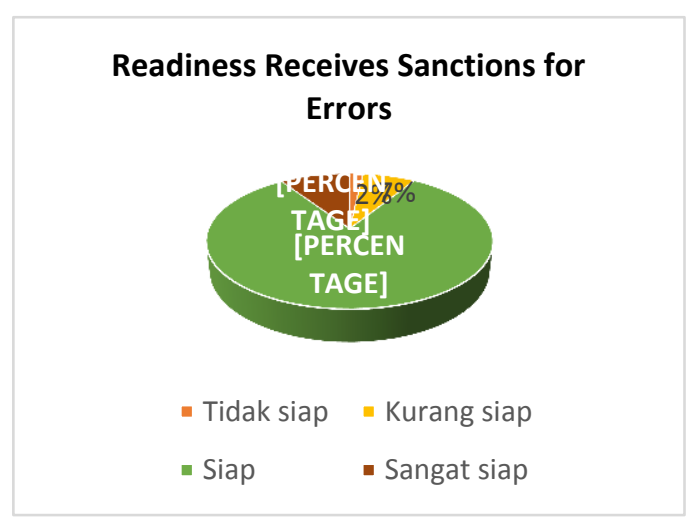

Figure 8. Readiness receives sanctions for errors

Employees are also very dissatisfied with the existence of double sanctions, i.e., when work is late and further sanctions arise from the accumulated delays. There are no rewards, only punsihment. If they are overtime compensated in the form of gratitude or other form of leadership. The majority of respondents are 
ready to accept sanctions for mistakes, but they are disappointed that the reward given is not proportional to the sanctions (Figure 8).

\section{Promotion and career development}

Career promotion and development are set out for employees in the form of promotional rules. Based on the FGDs, employees feel for peningakatan positions have been arranged and in accordance with the Ministerial Decree, such as class, term of office and education level. However, employees hope that promotion and development will be more open and transparent, including the criteria and benchmarks a person receives. This is so the person in charge of the position is responsible and acts appropriately.

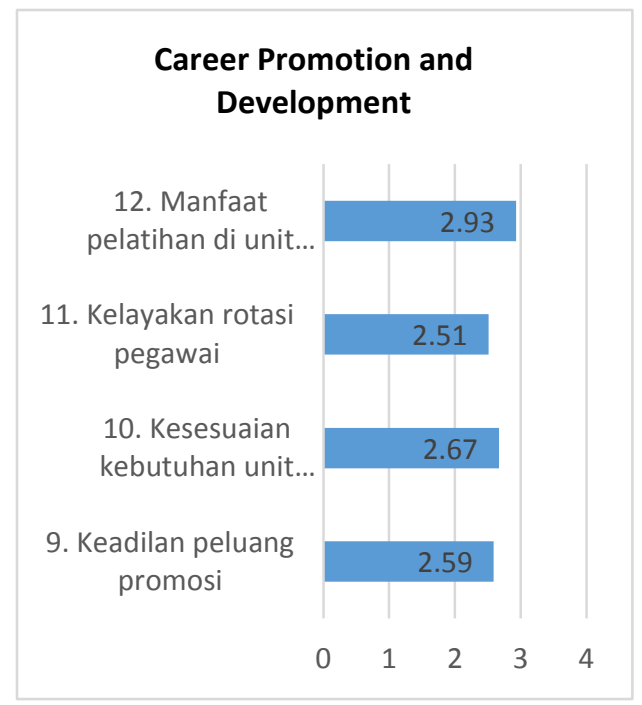

Figure 9. Career promotion and development

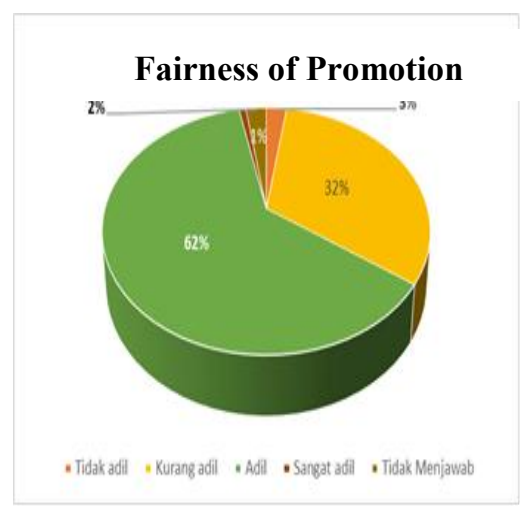

Figure 10. Fairness of promotion opportunities

Sixty-two percent of employees state that there are fair promotion opportunities. Employees also suggest that fit and proper tests need to be conducted periodically on officials and not just on initial recruits so that the quality of the state apparatus can be maintained (Figure 9). Employees have hope that leaders not only perform tasks but also become figures that are able to motivate, guide, and influence employees. It will be good for a comfortable working environment and not forcing employees. Employees consider the abilities of leaders in terms of planning, organizing, and managing to be low. Under KSN law, civil servants are required to be so that the competency tests and job auctions become the expected system (Figure 10). 


\section{Benefits of Training in Work Unit}

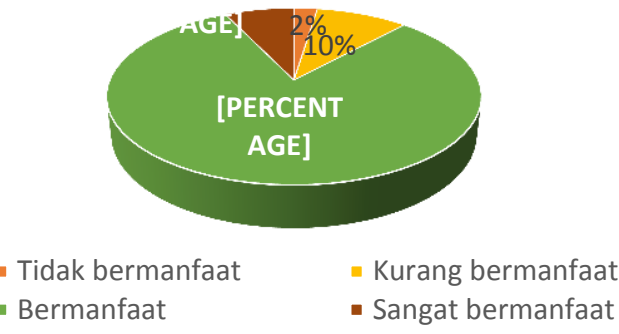

Figure 11. Benefits of training in the work unit

Eighty percent of employees feel the benefits of work unit training and hope there is a lot of bimtek training for them to support the work. Meanwhile, $51.18 \%$ stated the existence of eligibility for rotation of employees. Employees want regular rotation in order to maintain professional relationships (Figure 11).

\section{Assignment of work}

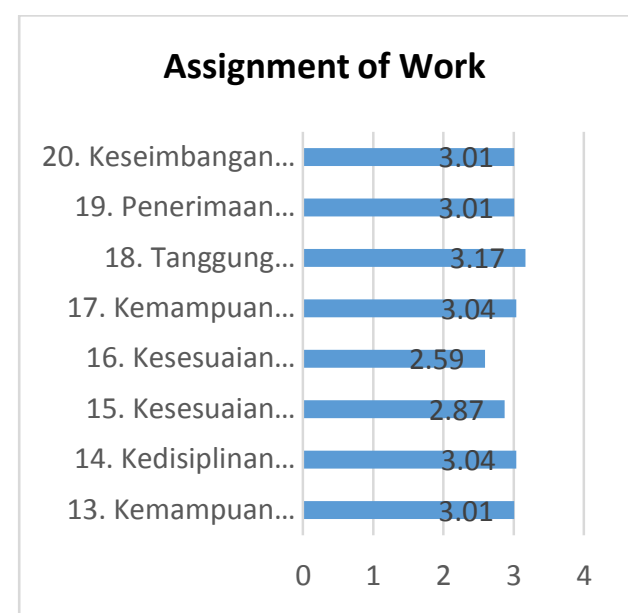

Figure 12. Assignment of work

Regarding job assignment not far from promotion promotion. More top down, but not yet a crucial issue like workload and compensation. In general, the conditions of teamwork in the work environment are good. This is indicated by most responses scoring above 3 (Figure 12). In addition, it is also very supportive of team performance as well as showing the capability of employees in receiving job assignments very well.

Figure 13. Balance of individual and team work

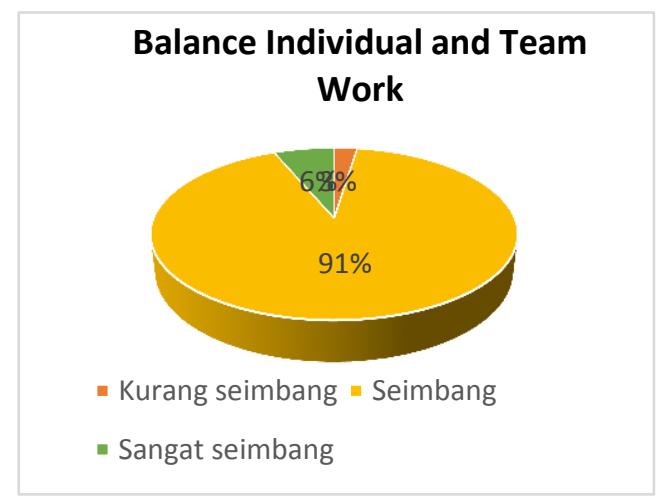

The balance between working individually and in a team is very high $(90.55 \%)$. The majority of respondents $(88.98 \%)$ are open to criticism, complaints or suggestions. Working responsibility is an indicator that can be 
achieved with the highest value (3.17) compared with the other indicators although the fit of the return schedule with workload is split into two votes between the corresponding (47.24\%) and the less fit (36.22\%) (Figure 13).

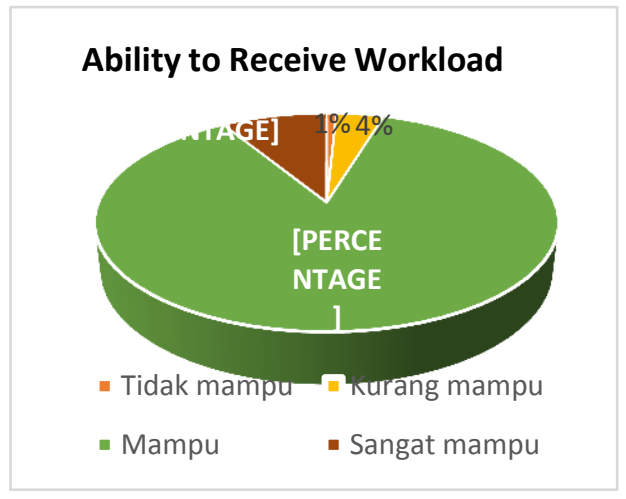

Figure 14. Ability to receive workload

The ability to perform tasks shows excellent numbers, with $85.83 \%$ stating they are able to accept the work load. In addition, $82.68 \%$ show work discipline, $65.35 \%$ arrive on time, and $85.83 \%$ are supported by good communication (Figure 14).

\section{Relationships with superiors}

Working relationships as well as relas outside working relationships vary among units within Ditejn PDN. It is personal, how the leadership can maintain cooperation with employees. In general, the value of the relationship with the supervisor below the score of 3 indicates the relationship is good.

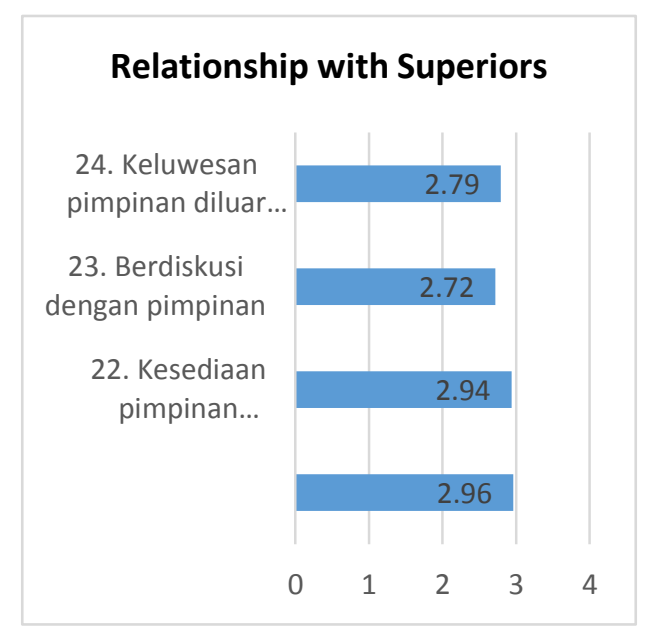

Figure 15. Relationship with superiors

Based on the indicators on the understanding of the direction of leadership, it can be said that most employees $(82 \%)$ understand the tasks of the leader and even $8 \%$ of respondents answered they understand those tasks very well; however, there are still $9 \%$ of employees who answer the date of understanding of the direction of leadership (Figure 15).

From the FGDs results, there are personal matters that can not be denied in the functional relationship of officials with employees disclosed. Among them, there are like and dislike elements. In general, employees want reliable leaders, and listen to their difficulties. One employee stated:

The boss only received the results but did not know how it was produced, but preparing it is not easy.

There are some units where employee work is not checked by the supervisor so employees never know whether the work is right or wrong. However, it is not generally accepted, there is a unit where the relationship 
between the employer and the employee goes well, is listened to, and assisted in solving the work problem. Appreciation by a younger supervisor to an older employee is also expected.

\section{Condition and work environment}

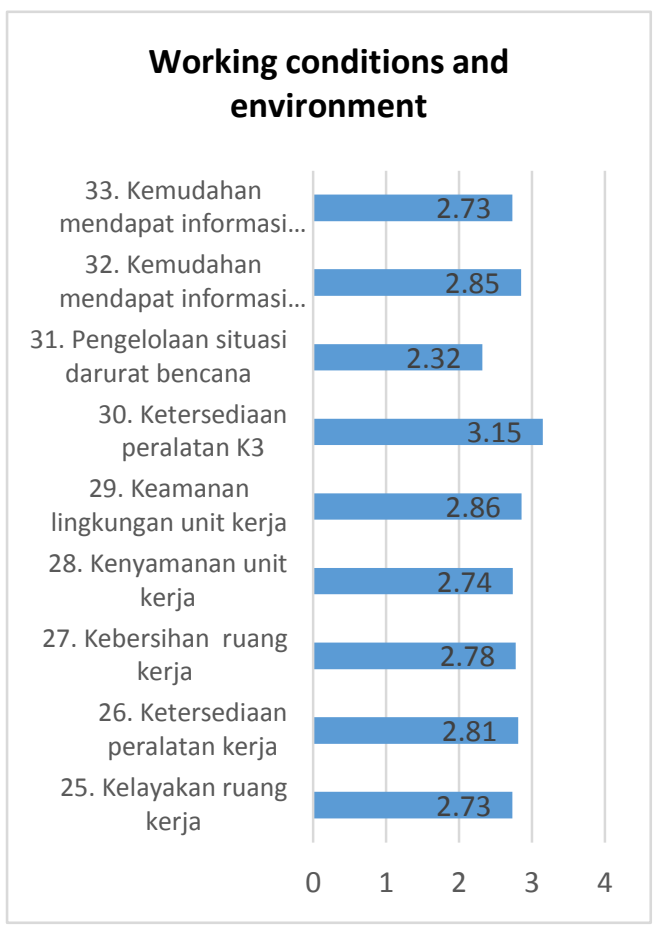

Figure 16. Working conditions and environment

The working conditions and environment are one aspect that can see employee responses to their job satisfaction in terms of fulfillment of physical and nun-physical aspects related to the carrying capacity of their work (Figure 16).

Although most of them have not got a score above 3 but it can be dismpulkan that in general aspects of conditions and work environment in the Directorate General of PDN is good except on the "disaster management emergency situation" with a score of 2.32 or below score 2.5 which means the tendency still not enough.

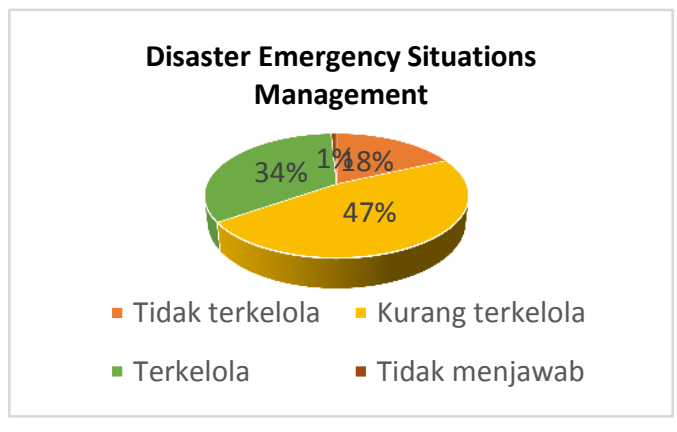

Figure 17. Disaster emergency situations management

The results graphed in Figure 17 show that Based on the Figure beside visible respondents feel less managed by $47 \%$, not managed by $18 \%$ and only $34 \%$ who answered already managed. The issue of disaster emergency is quite a concern lately due to the number of disasters that often strike various regions in Indonesia, including DKI Jakarta, which is the headquarters of the Directorate General of Domestic Affairs, Ministry of Trade (Figure 17). 


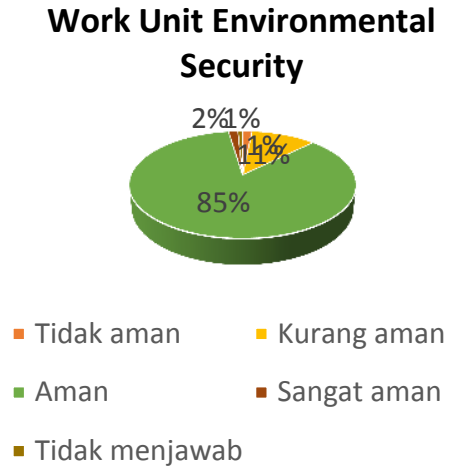

- Tidak aman $\quad$ - Kurang aman

- Aman - Sangat aman

- Tidak menjawab

Figure 18. Work unit environmental security

It is only natural that there is greater expectation by employees on the management of disaster emergency situations in their work environment so they can feel safe and comfortable in their daily work activities. However, in terms of security in general, $85 \%$ of respondents replied that their work environment is safe and only $11 \%$ declared it unsafe. In addition, positive responses show the are also shown in the indicator kebersiahn workspace, where $75 \%$ of respondents are clean and only $20 \%$ of respondents who answered still less clean (Figure 18).

\section{Work culture}

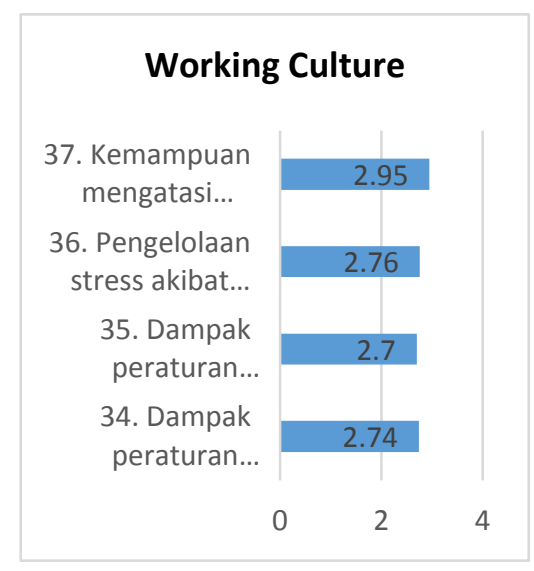

Figure 19. Work culture

Based on Figure 19, it can be said, in general, that the aspect of work culture in the Directorate General of PDN is good, with an average score above 2.5. The highest score is indicated in conflict resolution indicators with co-workers, with a total score of 2.95 . The lowest score is indicated by the new regulatory impact indicator for unit performance, with a score of 2.7 (Figure 19).

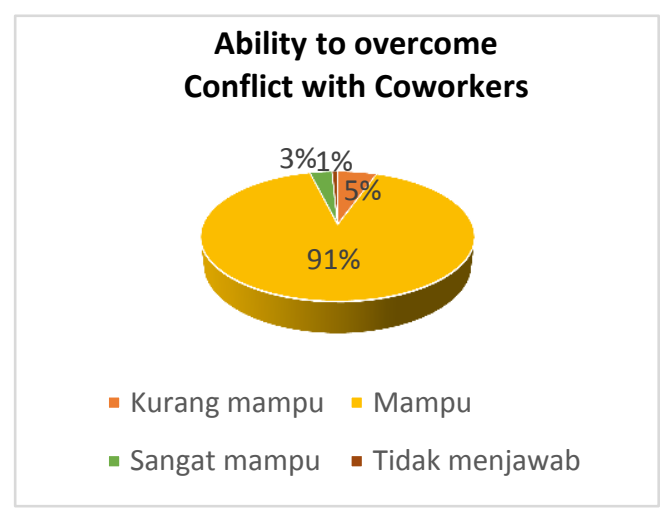

Figure 20. Ability to overcome conflict with co-workers 
Figure 20 shows that $91 \%$ of respondents answered that they are able to resolve conflicts with colleagues and $3 \%$ answered they resolve conflicts with colleagues very well. Meanwhile, for work stress management indicator, $76 \%$ indicated they are good but $18 \%$ indicated they are less good at managing work stress.

The results of the FGDs also indicate a lack of opportunities to manage relationships outside of work affairs. No outbound, as an interaction arena. Relationships based on the professional interests of the work done seriously. Almost, there is no time to gather by not doing the task. However, the ability to resolve conflicts with co-workers is very good. Evidently, the majority of respondents is able to resolve conflicts with colleagues. This shows the ability of individuals in mengeloal social interaction very well.

\section{Employee competencies}

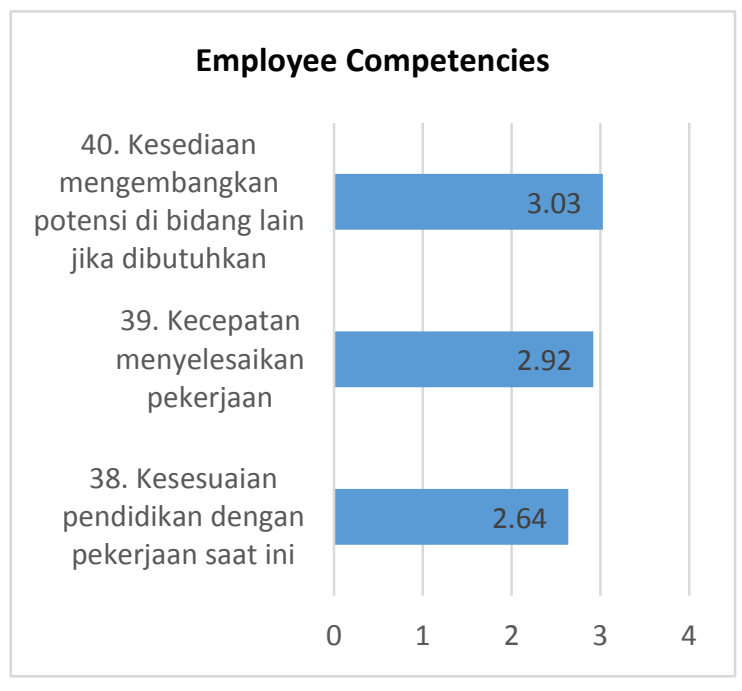

Figure 21. Employee competencies

Employee competence is observed on three indicators: employee perceptions of educational suitability with their current job, their ability to work on tasks, and the willingness of employees to develop themselves if needed (Figure 21).

On all three indicators, the survey shows that in general, employee competence has an average score above 2.5, where the highest score is seen for the indicator of willingness to float himself with a total score of 3.03 and the ability to complete the task with a score of 2.92. The lowest score is an indicator of educational conformity with the current job, with a score of only 2.64 .

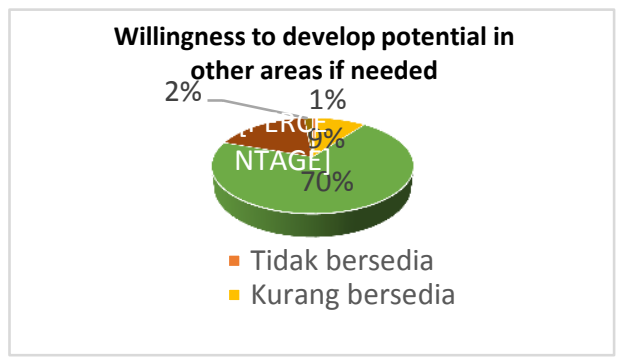

Figure 22. Willingness to develop potential in other areas if needed

The results of the FGDs results and related survey questions indicate that the competence of employees in the Directorate General of PDN is very good. Although there is no training or training for competence improvement, employees feel they are able to perform their tasks well, learning by doing, even just for socialization of guidance and technical to the important work. Employees expect the training to be divided into two parts, namely, administrative (archive) and functional (about trade, and other soft skill capabilities) (Figure 22).

Employees expect the employment bureau to be able to play a more prominent role, by enabling career paths for its employees, facilitated by the organization to achieve the highest level possible. 


\section{Conclusions}

Organizational restructuring involves enhancing roles, improving service quality, and adding value to stakeholders. However, restructuring is difficult to implement if the actors are unaware of the organizational goals. System improvement is the main focus. The results of this research show that employees are less satisfied with organizational management, compensation received, transparency of promotion and career development, workload, relationships with superiors, conditions and work environment, and most importantly development of employee competence within the organization.

The Directorate General of Domestic Trade has a good quality of human resources as evidenced by their readiness to accept sanctions, ability to run the workload, ability to communicate, have job responsibilities, openness to criticism and suggestions, balance work individually and team, colleagues, the ability to get things done quickly, and willing to develop potential in other fields if needed. These capabilities employees compromise with the conditions of the work environment, with not much demand. Just how the organization conducts change management and strategic direction determination, so that vision, and satisfaction both from employees and stakeholders can be achieved.

\section{References}

Creswell, John W. (2009). Research Design Pendekatan Penelitian Kualitatif,. Kuantitatif, dan Mixed. Yogyakarta: Pustaka Pelajar. Penterjemah Achmad

Hanggarini, Putu Mirah Ayu. (2012). Pengaruh Pengadaan SDM serta dan pendidikan Terhadap Kepuasan Kerja dan Kinerja Karyawan Bali Tourism Development Corporation (BTDC). Skripsi Sarjana Ekonomi Universitas Udayana, Denpasar.

Hasibuan, Malaya, (2012). Manajemen Sumber Daya Manusia, Jakarta : PT Bumi Aksara Sedarmayanti, 2007, Sumber Daya Manusia dan Produktivitas Kerja, Bandung, Penerbit Mandar Maju

Hasibuan, Malayu. (2010). Manajemen Sumber Daya Manusia. Cetakan Kesembilan. Jakarta: PT. Bumi Aksara

Morissan, M. (2012), Metode Penelitian Survei. Jakarta: Kencana, 